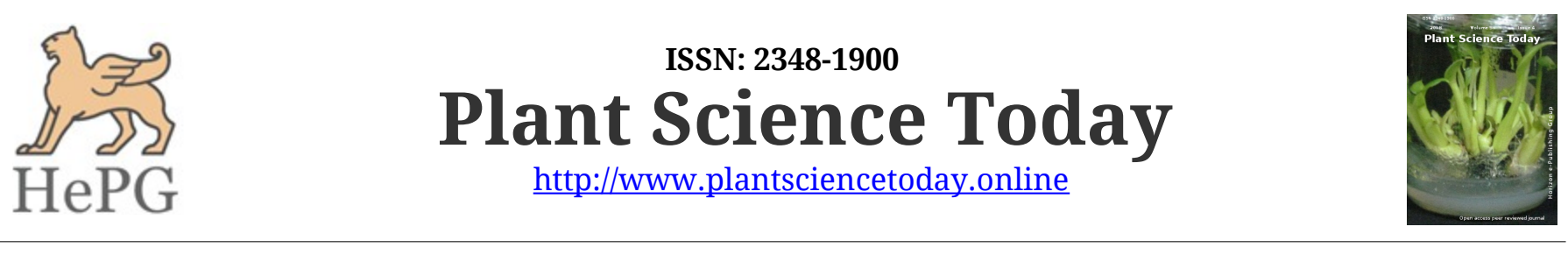

OPEN ACCESS

Research Communication

\title{
Two new additions to the flora of Vietnam
}

\author{
${ }^{* 1}$ V. S. Dang, ${ }^{2}$ N. T. N. Q. Ton, ${ }^{3}$ T. D. Truong, ${ }^{1}$ N. S. Hoang \\ ${ }^{1}$ Institute of Tropical Biology, Vietnam Academy of Science and Technology, 85 Tran Quoc Toan Street, District 3, Ho Chi Minh City, \\ Vietnam \\ ${ }^{2}$ Hue Medical College, 01 Nguyen Truong To Street, Hue City, Thua Thien Hue Province, Vietnam \\ ${ }^{3}$ University of Medicine and Pharmacy at Ho Chi Minh City, 41 Dinh Tien Hoang Street, District 1, Ho Chi Minh City, Vietnam
}

\section{Article history}

Received: 17 August 2018

Accepted: 18 September 2018

Published: 02 October 2018

\section{Editor}

Dr. E. S. Santhoshkumar, Jawaharlal Nehru Tropical Botanic Garden and Research Institute, India

\section{Publisher}

Horizon e-Publishing Group

\section{*Correspondence \\ Van Son DANG \\ 凶dvsonitb@gmail.com}

\begin{abstract}
Among the studied specimens collected from Son Tra Nature Reserve, Vietnam, two new taxa: Oxalis barrelieri L. (Oxalidaceae) and Glochidion acuminatum var. siamense Airy Shaw (Phyllanthaceae) which forms new records to the flora of Vietnam. Taxonomic description, habitat, distribution and uses, and color photographs of both taxa are provided.
\end{abstract}

Keywords

Oxalis; Glochidion; new record; Son Tra; Da Nang

\section{Citation}

Dang V S, Ton N T N Q, Truong T D, Hoang N S. Two new additions to the flora of Vietnam. Plant Science Today 2018;5(4):163-166. https://dx.doi.org/10.14719/pst.2018.5.4.417

Copyright: ( Dang et al. (2018). This is an open-access article distributed under the terms of the Creative Commons Attribution License, which permits unrestricted use, distribution, and reproduction in any medium, provided the original author and source are credited (https://creativecommons.org/licenses/by/4.0/).

\section{Introduction}

The genus Oxalis L. belonging to family Oxalidaceae consisting of over 800 species and is distributed in tropical and cold regions (1). Until now, three species and one variety of Oxalis have been recorded from Vietnam include $O$. corniculata L., $O$. deppei Lodd. ex Sweet, $O$. acetosella L. and $O$. debilis var. corymbosa (DC.) Lourteig (2).

Glochidion J. R. Forster \& G. Forster is one of the large genera in the family Phyllanthaceae and is represented by more than 300 species in the IndoPacific, east to southeast Polynesia and south into Australia (3, 4). Currently, about 22 species of Glochidion are known to occur in Vietnam $(2,5)$.

During a floristic exploration trip to Son Tra Nature Reserve, Da Nang City of Vietnam, we collected two unrecorded species of Oxalis and Glochidion in evergreen forest. After a detailed scrutiny of the literature and comparison of some species of genus Oxalis and Glochidion, they were identified as Oxalis barrelieri L. and Glochidion acuminatum var. siamense Airy Shaw. Hence, we report them as new records for the flora of Vietnam. A detailed description along with photographs, habitat, distribution and uses are provided.

\section{Materials and Methods}

The specimens collected from the field trip were preserved in the Herbarium of Institute of Tropical Biology (VNM) and the Herbarium of Son Tra Nature Reserve. We identified species by using the 


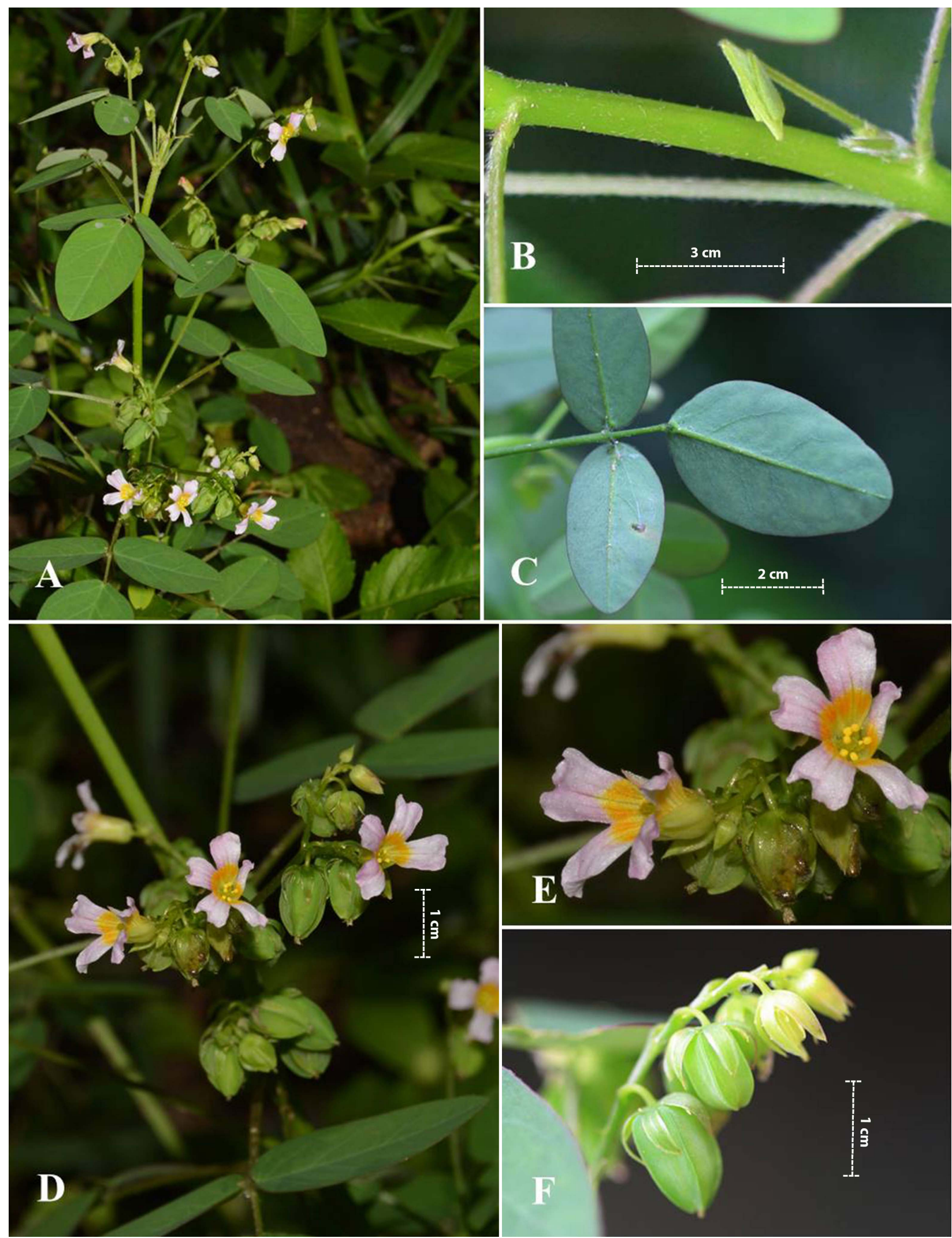

Fig. 1. Oxalis barrelieri L. (Ton et al. Q089): A. Habit, B. Internodes, C. Leaves pinnately 3-foliolate, D. Flowers and fruits, E. Flowers with the sepals and petals, F. Immature fruits.

following literature viz. Flora of Panama of Oxalis (1) and Flora of Thailand of Glochidion (6). The measurements and descriptions of floral characters were made from living plants and herbarium specimens. A Canon 1000D digital camera was used to take photographs of the material in the field.

\section{Taxonomic treatments}

1. Oxalis barrelieri L., Sp. Pl. ed. 2. 624. 1762 Acetosella barrelieri (L.) Kuntze, Rev. Gen. Pl. 1: 90. 1891. - Lotoxalis barrelieri (L.) Small, N. Amer. Fl. 25(1): 49. 1907.

Erect herb, up to $1 \mathrm{~m}$; stem green, pubescent. Leaves pinnately 3-foliolate, 


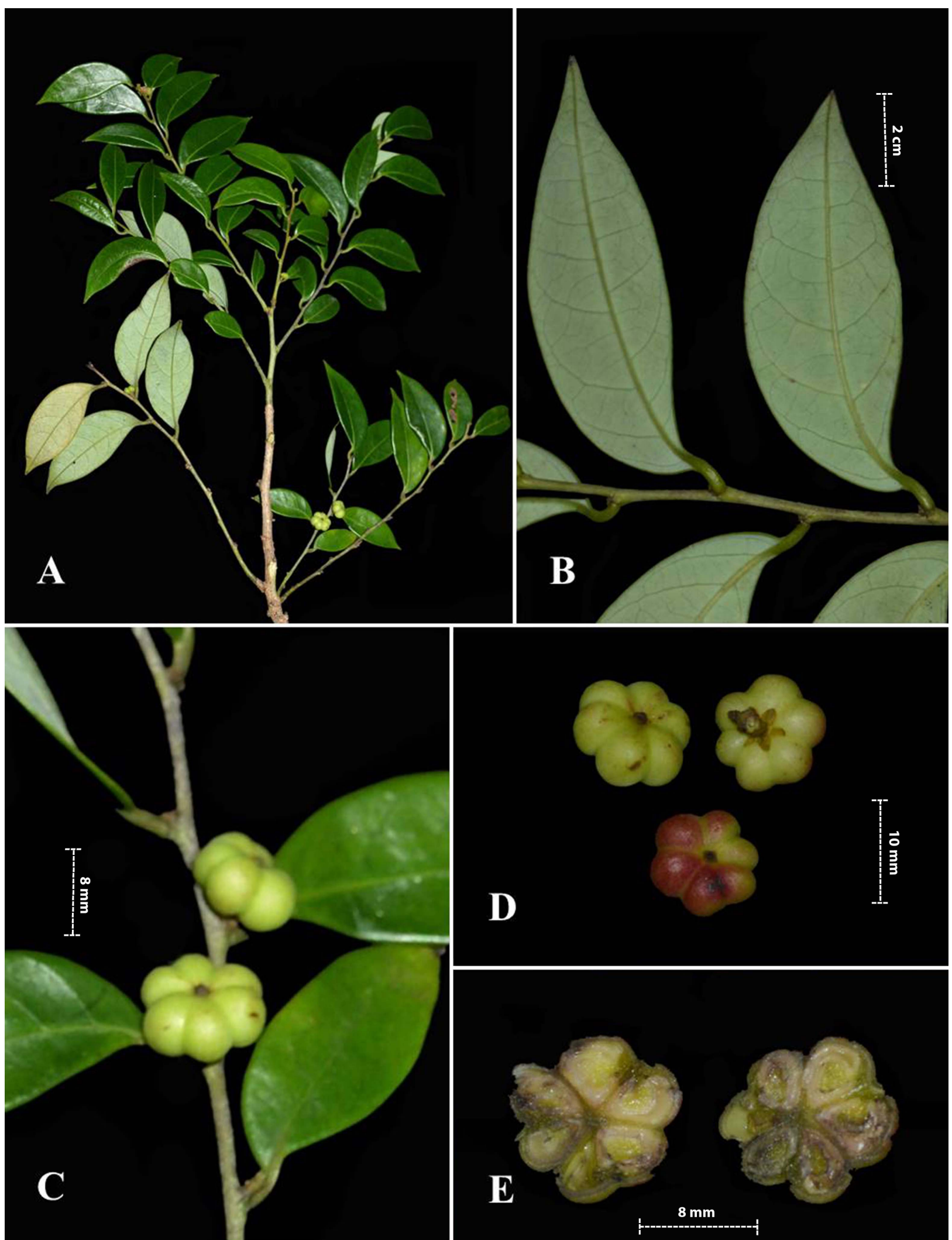

Fig. 2. Glochidion acuminatum var. siamense Airy Shaw (Ton et al. Q168): A. Branch, B. Abaxial surface of leaf, C. Branch with immature fruits, D. Immature fruits and ripe fruits. E. Transverse section of fruits.

exstipulate; leaflets sub-orbicular, oblong, ovate to elliptic, 0.8-5.5 × 0.6-2.5 cm, pubescent, base acute, roundish or subpeltate, margin entire, apex obtuse, seldom acute. Petioles 12-15 cm long; lateral petiolule $0.5-1 \mathrm{~mm}$ long, terminal petiolule 10-15 mm long. Inflorescence cymes, 4-10flowered; peduncles 6-6.5 cm long, pubescent; bracts lanceolate or triangular, 1.5-2 mm long, reddish, pilose; bracteoles smaller, appressed to the pedicel. Flowers with the sepals light green, 2$3.5 \times 1-1.5 \mathrm{~mm}$, ovate-lanceolate, acute, mucronate, pubescent, 3-nerved; petals white or yellowish at the throat and base, limb pink, obovate-lanceolate, apex rounded, 6-9 × 2-3.5 mm, glabrous; stamens 2-3 mm long, pubescent or glabrous; pistil 3-4 $\mathrm{mm}$ long, ovary ovoid, 
glabrous. Capsule slightly ovoid, 4-10 × 3-3.5 mm, apex and base 5-lobed, glabrous. Seeds brownish, ovoid-compressed, 1-2 mm long (Fig. 1).

Flowering and fruiting: July-November.

Habitat: Oxalis barrelieri was found growing in evergreen forest on rocky slopes and roadsides in association with Croton, Desmodium, Helicteres, Phyllanthus, Hedyotis at elevations about 400-500 $\mathrm{m}$.

Distribution: This species was found in tropical and subtropical America, cultivated and established in many places of the old World. In Vietnam, it only occurs in Son Tra Nature Reserve, Da Nang City, Central Vietnam.

Uses: Leaves edible and the whole plant for the treatment of many diarrhoeal diseases.

Notes: Oxalis barrelieri can be distinguished from the other four species (O. corniculata, O. deppei, $O$. acetosella and $O$. debilis var. corymbosa) in Vietnam by leaf pinnately 3-foliolate, petals white or yellowish at the throat and base with the pink limb.

Specimens examined: Vietnam. Da Nang City, Son Tra Nature Reserve, on rocky slopes and roadsides in evergreen forest, $16^{\circ} 07^{\prime} 00^{\prime \prime} \mathrm{N}, 108^{\circ} 16^{\prime} 49^{\prime \prime} \mathrm{E}, \pm 450$ $\mathrm{m}, 10$ August 2017, Ton $\mathrm{Nu}$ Thi Nhu Quynh, Nguyen Nguyen, Dang Van Son, Q089 (VNM, and the herbarium of Son Tra Nature Reserve).

2. Glochidion acuminatum var. siamense Airy Shaw, Kew Bull. 26: 273. 1972; Welzen in Welzen et al., Thai For. Bull. (Bot.) 28: 83. 2000; Welzen in Welzen \& Chayam., Fl. Thailand 8, 2: 310. 2007; Phytotaxa 236(1): 5. 2015. - Glochidion triandrum var. siamense (Airy Shaw) P. T. Li, Acta Phytotax. Sin. 26: 62. 1988; P. T. Li \& M. G. Gilbert, Fl. China 11: 197. 2008.

Shrubs or small trees, up to $6 \mathrm{~m}$. Leaves alternate, thickly papery, ovate to elliptic, usually falcate, 4-13 x 1.5-4.5 cm, coriaceous, base asymmetric, oblique to cuneate, margin entire, apex acute to gradually cuspidate, densely pubescent abaxially. Petioles 3-5 mm long. Stipules triangular, 1.5-3 $\mathrm{mm}$ long, caducous. Inflorescences axillary, bracteate fascicles. Sepals greenish to light yellow, outer ones 2-3 × 1-1.5 $\mathrm{mm}$, inner ones $1.5-2 \times 0.5-1 \mathrm{~mm}$, plicate, obovate, acute; stamens 3, 0.8-1.2 mm long, yellow, anthers 0.5-0.9 mm long; ovary 4 or 5-locular; stigmas 0.6 $1 \mathrm{~mm}$ long, yellow. Capsules round, apically and basally flattened, depressed above, ca. $10 \mathrm{~mm}$ in diam., pedicels robust, very short. Seeds triangular, ca. 3-3.2 × 2-2.5 mm, reddish brown (Fig. 2).

\section{Flowering and fruiting: May-Octorber.}

Habitat: The small population was found along the margin of evergreen forest, at ca. $400 \mathrm{~m}$, in an area dominated by Fabaceae, Rubiaceae, Euphorbiaceae and Rutaceae.
Distribution: This variety is distributed in China, Thailand and Vietnam (new record).

Uses: Young shoots edible.

Notes: Glochidion acuminatum var. siamense is similar to Glochidion acuminatum var. acuminatum, but distinguished by thickly papery leaves which is densely pubescent abaxially, capsules up to $10 \mathrm{~mm}$ in diam. and robust and very short pedicels.

Specimens examined: Vietnam, Da Nang City, Son Tra Nature Reserve, along margin in evergreen forest, $16^{\circ} 05^{\prime} 01^{\prime \prime N}, 108^{\circ} 14^{\prime} 39^{\prime \prime E}$, 400 m, 16 August 2017, Ton Nu Thi Nhu Quynh, Nguyen Nguyen, Dang Van Son, Q168 (VNM, and the herbarium of Son Tra Nature Reserve).

\section{Competing interest}

The authors declare that they have no competing interests.

\section{Authors' contributions}

All authors contributed equally to the work presented in this paper.

\section{Acknowledgements}

We thank the managers of the Son Tra Nature Reserve for their permission to carry out our field surveys. We are grateful to curators and staffs of herbaria VNM, HN and VNMN for their help to access specimens for this study and to Dr. Shuichiro Tagane of the Kagoshima University Museum, Kagoshima University, Japan for his help in the identification of the taxon and providing relevant literature.

\section{References}

1. Lourteig, A. 1980. Oxalidaceae In: Robert E. Wodson and Robert W. Schery (Eds) Flora of Panama I 67(1). Annales of the Missouri Botanical Garden, pp. 835-838.

2. Pham, H.H. 2000. An Illustrated Flora of Vietnam. vol. 2, Young Publishing house, Ho Chi Minh, Vietnam, pp. 202208 \& 295-296.

3. Govaerts, R, Frodin, D.G., Radcliffe-Smith, A., Carter, S. 2000. World checklist and bibliography of Euphorbiaceae (Pandaceae). Royal Botanic Gardens, Kew, UK, 1622 pp.

4. Li, P.T. \& Gilbert, M.G. 2008. Glochidion. In: Wu, Z.Y., Raven, P.H. (Eds) Flora of China 11. Science Press \& Missouri Botanical Garden Press, Beijing \& St. Louis, pp. 193-202.

5. Nguyen, N.T. 2007. Taxonomy of Euphorbiaceae in Vietnam. Vietnam National University Publishers, Hanoi, pp. 87-96.

6. van Welzen, P.C. 2007. Glochidion. In: Chayamarit, K. \& van Welzen, P.C. (Eds.) Flora of Thailand Vol. 8(2). Bangkok, pp. 308-331. 